\title{
Providing dismountable rivet bonded joints through the use of hot-melt adhesives
}

\author{
Natalia Baurova ${ }^{1, *}$, Alexander Anoprienko ${ }^{1}$, and Yulia Romanova ${ }^{1}$ \\ ${ }^{1}$ Moscow State Automobile and Road Technical University (MADI), 125319, Moscow, Leningradskii pr.64, Russia;
}

\begin{abstract}
The article presents the comparative analysis of adhesives used for obtaining rivet bonded joints. The dismantling characteristics of adhesive rivet bonded joints of different types are considered. It is shown that the application of hot-melt adhesives proved to be a far more advanced technique used for the materials being joined.
\end{abstract}

Today aluminum alloys and composites (carbon-filled plastics) are widely used in mechanical engineering. Joining parts from aluminum alloys or carbon-filled plastics to steel parts of the bearing frame is extremely difficult or impossible to perform with the use of traditional welding. For this reason the riveting technique has been increasingly used in mechanical engineering in recent years.

In the process of riveting, the protruding end of the shank is upset by hammer blows to form the closing head of a required shape and size [1]. This technology is more than 2000 years old. During excavations archeologists often discover various objects in which this joining technique was applied. At the beginning of the 19th century riveting was used as one of the main methods for producing permanent joints. The Eiffel Tower in Paris, for instance, is assembled directly with the application of rivets. However, the development of welding technology considerably reduced the sphere of applications of riveted joints. However, when manufacturing areas dealing with permanent joints started to use dissimilar materials, riveting moved to the foreground again.

In recent years riveted joints have also found use in the assembly of dissimilar materials or materials with poor weldability, heat-treated or finished precision components for which heating is prohibited, and as a result it is impossible to apply welding [2-3]. In certain cases riveting is the only method for producing joints.

The main disadvantages of riveted joints are high labour-intensive costs, high consumption of metal, weakness of the working cross-section and the effect of stress concentration caused by the holes required for rivets. The strength characteristics of riveted joints can be improved by adding glue (rivet bonding). The idea of rivet bonding is that the technique combines the two independent operations - «bonding» and «riveting». In mechanical engineering the process of making uncured rivet bonded joints has become the most widespread method. The core of this technological process is that rivets are fitted after the adhesive is applied, but before it is cured. [4].

Epoxy adhesives have been traditionally used to make joints [5]. The main application advantages of epoxy adhesives are good joint sealing, simplicity and low cost of this method, good corrosion resistance, no need for heating and lack of stress concentration in the joint area.

The drawbacks of epoxy materials include high requirements imposed on the quality of surface preparation, a long time of curing, toxicity and difficult dismounting. The high strength of glue and lack of thermoplasticity require additional power load and extra tools which definitely complicates dismantling. Furthermore, the faying surfaces of the bonded parts may be damaged while dismounting.

An alternative type of adhesives applied to create joints is hot-melt adhesives that are a form of thermoplastics [6-7]. Unlike epoxies that are thermosetting resins, hot-melt adhesives are reversible. Initially solid adhesives get melted and become viscousflow at elevated temperatures. Once adhesives cool, they revert to the original solid state. This method provides a strong bond line. Depending on a brand, bonding temperatures range between $100-200^{\circ} \mathrm{C}$ [7].

The basic requirements for hot-melt adhesives are a great bond strength and environmental resistance [8]. All that prevents the joint from altering its characteristics while in operation.

The advantages of hot-melt adhesives applied together with rivet bonded joints are that they are easily removed and provide increased strength and stiffness to structures under static, dynamic and vibration loads. This is because the structure distortion (e.g. in the three-point bending) is not accompanied by load-bearing points moving with respect to each other [9]. All these features increase the service life of rivet bonded joints.

Dismounting of rivet bonded joints with hot melt adhesives is ensured by the fact that thermoplastic hotmelt adhesives go to a liquid state and lose their

\footnotetext{
*Corresponding author: nbaurova@mail.ru
} 
tackiness when heated [10]. Table 1 shows the labour coefficient for assembly and dismounting of rivet joints, rivet bonded joints with epoxy adhesives and rivet bonded joints with hot-melt adhesives.

Table 1. The labour coefficient for assembly / dismounting of joints

\begin{tabular}{|l|c|c|}
\hline \multirow{2}{*}{ Type of joint } & \multicolumn{2}{|c|}{ The labour coefficient, \% } \\
\cline { 2 - 3 } & Assembly & Dismounting \\
\hline Rivet joint & 100 & 100 \\
\hline $\begin{array}{l}\text { rivet bonded joint } \\
\text { with epoxy } \\
\text { adhesive }\end{array}$ & 160 & 180 \\
\hline $\begin{array}{l}\text { rivet bonded joint } \\
\text { with hot-melt } \\
\text { adhesive }\end{array}$ & 160 & 130 \\
\hline
\end{tabular}

The sequence of operations on dismounting rivet bonded joints with hot-melt adhesive looks as follows: first, the bond line is cleaned, any dirt or paint, if there is any, is removed from the bond line. Then, rivets are drilled out (like during the process of rivet joint dismounting). After that the bond line is being heated with the hot air gun until the hot-melt adhesive gets melted (from 100 to $200^{\circ} \mathrm{C}$ ). When heated the solid adhesive becomes viscous-flow and joint surfaces get separated without any application of load. The rest of molten adhesive is removed from the plate surface with cloth. The result is a clean and tidy surface suitable for repeated bonding or riveting.

When producing rivet bonded joints with epoxy adhesive it is also necessary to observe the microclimatic parameters of a working area. High humidity causes curing to decelerate or even stop [5] whereas hot-melt adhesives are moisture resistant [10].

Thus, we can draw a conclusion that using thermoplastic hot-melt adhesives is one of the most efficient ways to manufacture rivet bonded joints.

Hybrid joints combining adhesive bonding with rivet joints can generally be created in one of three ways:

- the sequential method (installing rivets after the adhesive layer has hardened);

- the «fixing» method (installing rivets before adhesives have cured);

- the injection method (joining parts with a rivet joint before injecting the adhesive into the gap between the components).

Each of these technologies has advantages and disadvantages (table 2). The choice of technology is based on the conditions of a particular production. If the parts are assembled for single-unit production, then the first and third technologies are the most effective. The application of the second technology is preferable for mass production. This is due to the fact that this technology does not require any changes in riveting modes and the equipment earlier used for riveting can be applied.
The «fixing» method (when joining the components together is followed by the hardening of the adhesive layer) is widely used for automotive body repairs.

This alternative technology provides a higher level of joint efficiency compared to adhesive bonding, riveting or the technology when rivets are installed after the adhesive has cured. The «fixing» method also enables to use technologically recent adhesives providing a strong adhesive layer.

The principle drawbacks of the method are the rivet tool contamination caused by excessive uncured adhesive and the increased drill wear [3].

Table 2. Comparison of different methods of creating rivet bonded joints

\begin{tabular}{|c|c|c|}
\hline $\begin{array}{l}\text { Methods of } \\
\text { creating } \\
\text { rivet } \\
\text { bonded } \\
\text { joints }\end{array}$ & Advantages & Drawbacks \\
\hline $\begin{array}{l}\text { The «fixing» } \\
\text { method: } \\
\text { riveting } \\
\text { before } \\
\text { adhesive } \\
\text { curing }\end{array}$ & $\begin{array}{l}\text { - high quality of } \\
\text { the adhesive } \\
\text { layer; } \\
\text { - a wide range } \\
\text { of adhesives }\end{array}$ & $\begin{array}{l}\text { - } \\
\text { contamination } \\
\text { of drills by } \\
\text { excessive } \\
\text { uncured } \\
\text { adhesive }\end{array}$ \\
\hline $\begin{array}{l}\text { The } \\
\text { sequential } \\
\text { method: } \\
\text { riveting after } \\
\text { adhesive } \\
\text { curing }\end{array}$ & $\begin{array}{l}\text { - uniform } \\
\text { thickness of the } \\
\text { adhesive layer; } \\
\text { - no clamping is } \\
\text { required; } \\
\text { - a wide range } \\
\text { of adhesives }\end{array}$ & $\begin{array}{l}\text { - potential } \\
\text { damage of the } \\
\text { adhesive layer } \\
\text { while rivet; } \\
\text { - the increased } \\
\text { wear of drills }\end{array}$ \\
\hline $\begin{array}{l}\text { The } \\
\text { injection } \\
\text { method: } \\
\text { riveting } \\
\text { before } \\
\text { adhesive } \\
\text { injecting }\end{array}$ & $\begin{array}{l}\text {-high quality of } \\
\text { the adhesive } \\
\text { layer }\end{array}$ & $\begin{array}{l}\text { - a special tool } \\
\text { is required to } \\
\text { apply the } \\
\text { adhesive; } \\
\text { - the increased } \\
\text { assembling } \\
\text { time required } \\
\text { for adhesive } \\
\text { hardening; } \\
\text { - the limited } \\
\text { range of } \\
\text { adhesives }\end{array}$ \\
\hline
\end{tabular}

The quality of rivet bonded joints depends to a large extent on a rivet and adhesive type chosen. Being placed like weld points with a certain span the rivet holes represent further stress raisers. Therefore, each type of joint requires a particular type of rivet.

The hybrid joints used in the automobile industry and machine building are mainly based on two rivet types: blind and metal piercing rivets. Typically, metal piercing rivets are called «self-piercing» due to the fact that their installation does not require any pre-drilled holes. Selfpiercing rivet bonded joint is shown in fig.1. However, they can be installed on a flat surface only (with no high spots), e.g. in door openings or window screens. While setting such rivets the protrusion is formed on one side 
only. At the same time the rivet 'cap' is positioned close to the part surface that allows it to be almost imperceptible after painting. The main disadvantage of self-piercing rivets is that their installation requires special equipment whereas blind rivets are installed with traditional riveting hammers.

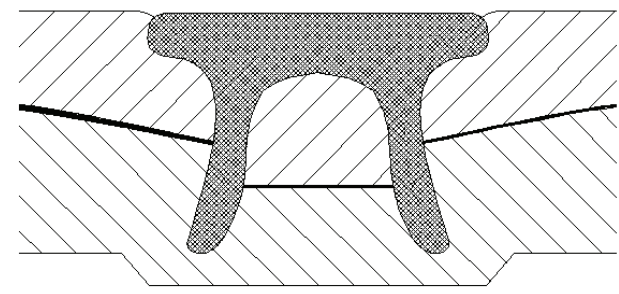

Fig.1. Self-piercing rivet bonded joint.

Blind rivets require pre-drilled holes. Therefore, the use of such rivets is undesirable for the assembly of large machine parts with numerous holes because there is a high risk of the holes' mismatch caused by the displacement of plates relative to each other. Blind rivet bonded joint is shown in fig. 2 .

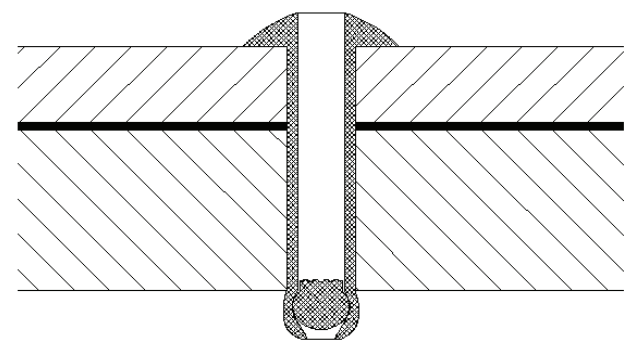

Fig.2. Blind rivet bonded joint.

Rivet joints comply with the condition according to which any mechanical loads are taken by rivets. However, rivet bonded joints do not satisfy it, for the adhesive applied shares load stresses with the rivet [5]. The long bond line results in the redistribution of stresses. Therefore, the span between rivets can be increased.

The type of adhesive depends on a particular method applied to create a rivet bonded joint. Riveting before adhesive curing allows film, phenol-formaldehyde and hot or cold cure epoxy adhesives to be used because in comparison to other methods of rivet bonding this one provides no restrictions on stress-strain behavior of adhesive (i.e. on its brittleness). When a rivet bonded joint is subjected to loadings the adhesive layer takes a large part of stresses thereby relieving rivets and reducing the strain of plates. For this reason, cold cure epoxy adhesives with encapsulants are a more perspective material used for automotive body repairs [8-9]. Fig.3 shows the behavior of epoxy adhesive with encapsulants under shear stress $50 \%$ of failure load.

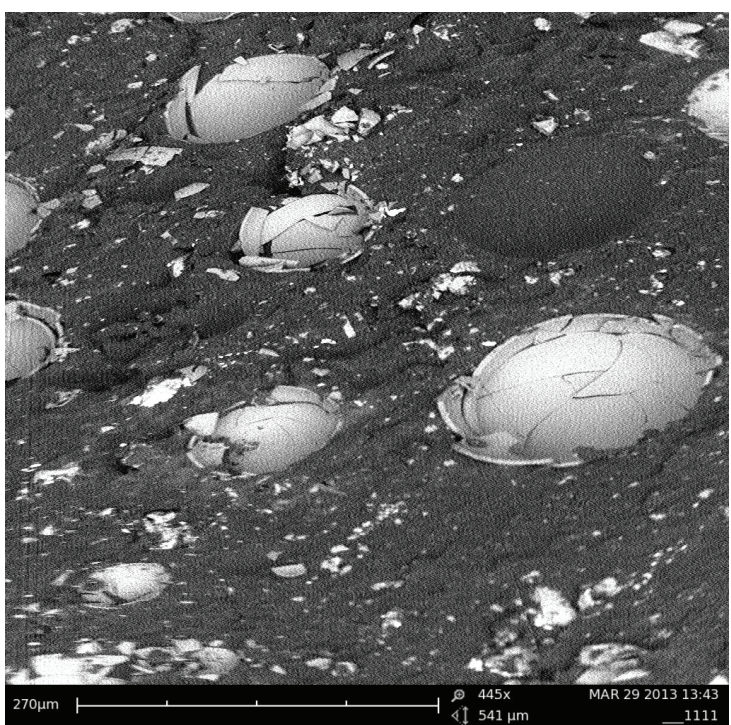

Fig.3. Epoxy adhesive with encapsulants under shear stress $50 \%$ of failure load.

The analysis of strength characteristics of different rivet bonded joints is given in accordance with industry standards GOST 1.00872-77 [10]. Some tests were performed to determine the maximum shear load of rivet bonded joints. The test samples of rivet and rivet bonded joints comply with the requirements of GOST 6996-66. The test results are presented in Table 3. Once the tests have been conducted, mean failure load is calculated.

Table 3. Test results of the calculations of maximum shear load

\begin{tabular}{|l|c|}
\hline \multicolumn{1}{|c|}{ Test subject } & $\begin{array}{c}\text { Max. shear load, } \\
\text { kgf (N) }\end{array}$ \\
\hline Blind riveted joint & $245(2402)$ \\
\hline $\begin{array}{l}\text { blind rivet bonded } \\
\text { joint }\end{array}$ & $246(2413)$ \\
\hline $\begin{array}{l}\text { Self-piercing } \\
\text { riveted joint }\end{array}$ & $251(2462)$ \\
\hline $\begin{array}{l}\text { self-piercing rivet } \\
\text { bonded joint }\end{array}$ & $301(2952)$ \\
\hline
\end{tabular}

The tests have shown that self-piercing rivet bonded joints provide the greatest shear strength whereas adding adhesives to blind riveted joints has not affected their strength. If rivet bonding of plates with different thickness is required, the strength of such joints is to be somewhat poorer compared to that provided by plates of uniform thickness. To reduce the negative effect of uneven gauge it is necessary to place the closing head on the side of a thicker plate. Thus, the use of modern rivets and adhesives allows the adhesive layer to take a greater part of stresses that, in turn, leads to the extended service life of joints and the reduced material deformation.

The fault cause analysis and possible preventive measures (remedies) are shown in Table 4. 
Table 4. Typical faults in rivet bonded joints, causes and remedies

\begin{tabular}{|c|c|c|c|}
\hline $\begin{array}{c}\text { № } \\
\text { II/III }\end{array}$ & Fault & Cause & Remedy \\
\hline 1. & $\begin{array}{l}\text { Deflection of } \\
\text { joining plates }\end{array}$ & $\begin{array}{l}\text { Excessive } \\
\text { pressure on } \\
\text { plates. } \\
\text { Diameter of } \\
\text { rivet shaft is } \\
\text { larger than } \\
\text { diameter of } \\
\text { hole (the rivet } \\
\text { is set } \\
\text { forcefully) }\end{array}$ & $\begin{array}{l}\text { Check the } \\
\text { amount of } \\
\text { force applied } \\
\text { while setting } \\
\text { the rivet. } \\
\text { Check hole } \\
\text { dimensions } \\
\text { correspond to } \\
\text { the diameter } \\
\text { of the rivet } \\
\text { shank }\end{array}$ \\
\hline 2. & $\begin{array}{l}\text { Metal swell } \\
\text { under the rivet } \\
\text { heads }\end{array}$ & $\begin{array}{l}\text { Riveting was } \\
\text { performed } \\
\text { without } \\
\text { upsetting the } \\
\text { rivet spots by } \\
\text { straining tie }\end{array}$ & $\begin{array}{l}\text { Upset the rivet } \\
\text { spots by } \\
\text { straining tie }\end{array}$ \\
\hline 3. & $\begin{array}{l}\text { Hollows on } \\
\text { joining plates } \\
\text { and rivet } \\
\text { heads }\end{array}$ & $\begin{array}{l}\text { The wrong } \\
\text { choice of tool, } \\
\text { careless work }\end{array}$ & $\begin{array}{l}\text { Use dedicated } \\
\text { upsetting }\end{array}$ \\
\hline 4. & $\begin{array}{l}\text { Incomplete } \\
\text { closing head }\end{array}$ & $\begin{array}{l}\text { The wrong } \\
\text { choice of rivet } \\
\text { type } \\
\text { (the rivet shank } \\
\text { is shorter than } \\
\text { it is supposed } \\
\text { to be) }\end{array}$ & $\begin{array}{l}\text { Calculate the } \\
\text { optimum } \\
\text { length of the } \\
\text { rivet shank } \\
\text { and check } \\
\text { presorting of } \\
\text { rivets for } \\
\text { those of } \\
\text { required } \\
\text { length has } \\
\text { been } \\
\text { performed }\end{array}$ \\
\hline 5. & $\begin{array}{l}\text { Deformation } \\
\text { (bend) of rivet } \\
\text { shaft }\end{array}$ & $\begin{array}{l}\text { The rivet shank } \\
\text { of excessive } \\
\text { length or } \\
\text { misalignment } \\
\text { of rivet axes } \\
\text { and the } \\
\text { bucking tool }\end{array}$ & $\begin{array}{l}\text { Check the } \\
\text { geometry of } \\
\text { rivets } \\
\text { corresponds to } \\
\text { the } \\
\text { calculations } \\
\text { made }\end{array}$ \\
\hline 6. & $\begin{array}{l}\text { Shank } \\
\text { flattening }\end{array}$ & $\begin{array}{l}\text { Clearance gap } \\
\text { between joined } \\
\text { parts }\end{array}$ & $\begin{array}{l}\text { Check the } \\
\text { geometry and } \\
\text { proper } \\
\text { bearing of } \\
\text { parts }\end{array}$ \\
\hline 7. & $\begin{array}{l}\text { Gapping } \\
\text { between the } \\
\text { closing head } \\
\text { and the die } \\
\text { head }\end{array}$ & $\begin{array}{l}\text { The rivet head } \\
\text { not tightly set }\end{array}$ & $\begin{array}{l}\text { Check the } \\
\text { rivet head is } \\
\text { set tight. } \\
\text { Remove any } \\
\text { contamination } \\
\text { as well as } \\
\text { facings out of } \\
\text { holes }\end{array}$ \\
\hline
\end{tabular}

\begin{tabular}{|c|c|c|c|}
\hline 8. & $\begin{array}{l}\text { Mismatch } \\
\text { between the } \\
\text { closing head } \\
\text { and the die } \\
\text { head }\end{array}$ & $\begin{array}{l}\text { Displacement } \\
\text { of parts before } \\
\text { or during the } \\
\text { process of } \\
\text { riveting. } \\
\text { Angular } \\
\text { position of drill } \\
\text { while in } \\
\text { operation }\end{array}$ & $\begin{array}{l}\text { Provide } \\
\text { visual } \\
\text { inspection } \\
\text { during the } \\
\text { process of } \\
\text { drilling. } \\
\text { Make sure } \\
\text { parts to be } \\
\text { riveted are } \\
\text { fixed and } \\
\text { unmoved }\end{array}$ \\
\hline 9. & $\begin{array}{l}\text { Misalignment } \\
\text { of rivets }\end{array}$ & $\begin{array}{l}\text { Non-uniform } \\
\text { thickness of } \\
\text { bond line, } \\
\text { displacement of } \\
\text { parts while } \\
\text { adhesive } \\
\text { bonding }\end{array}$ & $\begin{array}{l}\text { Provide pre- } \\
\text { spacing of } \\
\text { rivet holes, } \\
\text { make sure } \\
\text { parts to be } \\
\text { riveted are } \\
\text { fixed and } \\
\text { unmoved }\end{array}$ \\
\hline 10. & Starved spots & $\begin{array}{l}\text { Initial poor fit } \\
\text { of parts } \\
\text { (increased } \\
\text { clearance } \\
\text { between joining } \\
\text { parts). Air } \\
\text { inclusions and } \\
\text { voids in bond } \\
\text { line. }\end{array}$ & $\begin{array}{l}\text { Check the } \\
\text { geometry and } \\
\text { firm } \\
\text { adherence of } \\
\text { parts. } \\
\text { Check the } \\
\text { thickness and } \\
\text { uniformity of } \\
\text { adhesive } \\
\text { layer. } \\
\text { Comply with } \\
\text { adhesive } \\
\text { bonding } \\
\text { technology }\end{array}$ \\
\hline 11. & $\begin{array}{l}\text { Low adhesive } \\
\text { strength }\end{array}$ & $\begin{array}{l}\text { Contaminated } \\
\text { surfaces of plates } \\
\text { to be bonded. } \\
\text { failure of cooling } \\
\text { modes for } \\
\text { adhesive }\end{array}$ & $\begin{array}{l}\text { Check } \\
\text { pretreatment } \\
\text { procedures } \\
\text { are correct. } \\
\text { Observe the } \\
\text { dedicated } \\
\text { temperature } \\
\text { modes and } \\
\text { provide } \\
\text { accurate time } \\
\text { control while } \\
\text { hot-melt } \\
\text { heating or } \\
\text { cooling }\end{array}$ \\
\hline
\end{tabular}

The quality control test takes an important part in the creation of rivet bonded joints. At an early stage it is monitored by visual inspection that there are no such faults as:

- undue local deformation of joining parts including their deflection while setting the rivet and metal swell under the rivet heads (this fault mostly occurs while riveting metal sheet $5 \mathrm{~mm}$ and thicker); hollows on joining plates and rivet heads.

- incomplete closing head;

- deformation (bend) and flattening of the rivet shank;

- gapping between the closing head and the die head; 
-mismatch between the closing head and the die head along with misalignment of rivets;

- starved spots or peeling (low adhesive strength).

Thus, the tests conducted allow us to draw a conclusion that the adhesive used in a rivet bonded joint of high quality not only protects the inner surfaces of substrates from corrosion but also seals the joint off. It was found that rivet bonded joints provide a greater shear strength (by 15-35\%), even tear (by $20 \%$ ) and uneven tear (by 25-40\%) than corresponding rivet joints $[1,5,9]$. Furthermore, rivet bonded joints show better strength characteristics under dead-load stresses and vibration strain than similar rivet joints.

\section{References}

1. N. Lapina, N. Baurova, Polym. Sci., Ser. D, 9(3), 326-330 (2016).

2. V. Zorin, Mechaniz. Stroitelst, 77(10), 43-46 (2016).

3. N. Baurova, V. Zorin., V. Prikhodko, Polym. Sci., Ser. D, 9(4), 402-406 (2016).

4. A. Konoplin, Remont. Vosstan. Moderniz, 8, 37-39 (2016).

5. A. Konoplin, Vsematerial. Encicloped. Sprav., 7, 10-14 (2015).

6. G. Malysheva, M. Shablygin, T. Guzeva, Fibre Chemistry, 47(2), 85-88 (2015).

7. A.Borodulin, A. Marycheva, G. Malysheva, Glass Physics and Chemistry. 41(6), 660-664 (2015)

8. A. Sergeyev, R. Turusov, N. Baurova, A. Kuperman, Mechan. of Comp. Mat. 51(3), 321-332 (2015)

9. V. Nelyub, Fibre Chemistry. 47(1), 40-42 (2015)

10. V. Zorin, Mechaniz. Stroitelst., 77(1), 12-15 (2016) 